TheJournalish: Social and Government

http://thejournalish.com/ojs/index.php/thejournalish/index

Volume 1 Nomor 4 Desember 2020: TheJournalish

Hal. 137-149

\title{
Pengaruh Tagar \#2019gantipresiden Terhadap Partisipasi Politik Milenial
}

\author{
Muhammad Iqbal Themi ${ }^{1}$, Aditya Perdana ${ }^{2}$ \\ ${ }^{1,2}$ Departemen Ilmu Politik Universitas Indonesia, Jl.Margonda Raya, Kota Depok, Jawa Barat \\ Corresponding Author: themiiqbal26@gmail.com
}

\begin{abstract}
Abstrak: Evolusi perkembang internet dan munculnya media baru (Media Sosial) mempengaruhi banyak peristiwa politik, yang paling sering disoroti adalah terkait pengaruh penggunaan media sosial terhadap partisipasi politik. Namun sejauh ini literatur yang ada hanya menunjukan pengaruh langsung antara penggunaan media sosial dan partisipasi politik tanpa proses mekanisme psikologis yang terjadi. Selain itu, fenomena tagar di Indonesia juga kurang mendapat perhatian para ilmuwan padahal tagar sebagai bagian dari konsep viralitas memiliki kemampuan penyebaran informasi dalam skala besar dan cepat bahkan dalam beberapa kasus mempengaruhi gerakan sosial. Oleh karena itu, artikel ini berupaya untuk menguji pengaruh konten tagar \#2019GantiPresiden terhadap partisipasi politik online dan offline (low/high) dengan menggunakan Model Partisipasi Politik Media Sosial (SMPPM). Adapun metode yang digunakan adalah kuantitatif dengan teknik pengumpulan data berdasarkan kuisioner dan teknik analisa regresi linier sederhana. Hasilnya (1) pengaruh tagar \#2019GantiPresiden terhadap partisipasi online (low/high) lebih besar dibanding terhadap partisipasi offline (low/high), (2) konten tagar \#2019GantiPresiden tidak memiliki tujuan partisipatif dan dan tidak lebih dominan dibanding tujuan individu sekalipun mereka sepakat dengan tagar tersebut, sehingga (3) tidak dapat meningkatkan rata-rata responden yang pernah melakukan partisipasi onlineloffline (low) menuju partisipasi online/offline (high).
\end{abstract}

Kata Kunci: Mekanisme Psikologis; Partisipasi Politik; Media Sosial, tagar \#2019GantiPresiden dan Viralitas.

\begin{abstract}
The internet development evolution and the emergence of new media era (Social Media) has been influencing a lot of politics' phenomena, the previous studies have only shown a direct impact between the social media users and political participation without involving a psychological mechanism. Furthermore, the hashtag phenomena in Indonesia gained less attention from the scientists, although a hashtag as a virality concept has an amazing speed and a huge scale of spreading the information that even in a few cases has already influencing a social movement. Hence, this article is trying to examine the influence of a content that uses hashtag \#2019GantiPresiden towards both the online participation (low/high) and offline participation (low/high) using Social Media Political Participation Model (SMPPM). This article using quantitative method with data collection techniques based on questionnaires and simple linear regression analysis techniques. The results (1) the influence of \#2019GantiPresiden's hashtag towards the online participation (low/high) is bigger than the offline participation (low/high), (2) The \#2019GantiPresiden's hashtag content has no participatory goals and is not more dominant than individual goals even if they agree with the hashtag, so that (3) the result has no ability in increasing the average number of respondents who have participated online/offline (low) towards the online/offline participation (high).
\end{abstract}

Keywords: \#2019GantiPresiden's hashtag, Political Participation, Psychological Mechanism, Social Media, and Virality.

Article History:

Received: 28-11-2020; Revised: 1-12-2020; Accepted: 8-12-2020.

\section{PENDAHULUAN}

Media sosial merupakan salah satu produk dari evolusi internet dan bentuk dari komunitas virtual. Perkembangan media sosial diawali dengan penemuan situs layanan web hosting tahun 1995 yaitu GeoCities. Sejak saat itu muncul beragam website di seluruh dunia seperti Classmates (1995), Sixdegree (1997), Blogger (1999), Friendster (2002), LinkedIn (2003), Myspace (2003), Facebook (2004), Twitter (2006) dan Instagram (2011). Perkembangan internet juga mempengaruhi berbagai 
fenomena politik seperti "Unjuk Rasa Web 2.0" di Korea selatan (2008), "Arab Spring" di Tunisia (2011), Revolusi Payung atau Umberella Hongkong (2014) dan yang lainnya. Menurut Bannett dan Segerberg (2012) fenomena demikian menunjukan transformasi jaringan gerakan sosial dan perubahan paradigma dari aksi "kolektif" ke aksi "konektif" atau dengan kata lain aksi kolektif dari gerakan sosial semakin difasilitasi oleh penggunaan media sosial (konektif).

Media sosial berkembang seiring dengan meluasnya akses internet di berbagai negara termasuk Indonesia. Menurut penelitian We Are Social (2020) penggunaan media sosial di Indonesia semakin meningkat dan rata-rata orang Indonesia menghabiskan 3 jam 23 menit sehari untuk mengakses media sosial. Sedangkan disisi lain berdasarkan laporan The Economist Intelligence Unit (EIU) index partisipasi Indonesia mengalami penurunan dari 6.67 (2016-2018) menjadi 6.11 (2019). Fenomena tersebut merupakan anomali mengingat banyak ilmuwan memandang media sosial dapat meningkatkan partisipasi politik (Howard, et al., 2011; Small, 2011; Martin, 2016).

Adapun pengguna media sosial terbanyak di Indonesia berada pada dua kategori rentang usia yakni 18-24 (33\%) dan 25-34 (33\%). Pada rentang usia 18-24 persentase terbanyak laki-laki 18\% dan perempuan 15\%, sedangkan pada rentang usia 25-34 persentasi terbanyak laki-laki 19\% dan perempuan $14 \%$. Kedua kategori rentang usia tersebut pada dasarnya sesuai dengan kategorisasi generasi milenial menurut Lembaga Survei Indonesia (LSI) yakni kategorisasi milenial dalam rentang usia 17-39 tahun. Di sisi lain, studi Christiany Juditha dan Joseph J. Darmawan (2018) menunjukan bahwa topik politik dianggap biasa saja (40,5\%) oleh generasi milenial, bahkan hanya berkisar 5,2\% hingga 5,8\% dari responden yang mau terlibat dalam mengkritisi pemerintah. Penelitian terbaru terkait generasi milenial dan politik dilakukan oleh IDN Research Institute, hasilnya menunjukan bahwa "milenial adalah nasionalis tanpa kepentingan politik. Mereka tidak tertarik pada politik tetapi komitmen dan concern untuk meningkatkan dan melindungi Indonesia”. Dari data yang disajikan hanya $23.4 \%$ milenial yang mengikuti isu perkembangan politik. Hal ini menarik karena peningkatan jumlah pengguna internet dan media sosial di Indonesia cukup tinggi terutama di kalangan anak muda sedangkan partisipasi politik kalangan muda justru rendah.

Rendahnya ketertarikan dan partisipasi generasi Milenial terhadap politik sudah banyak dibahas. Misalnya Studi Yolanda dan Halim (2020) menemukan kebanyakan bentuk partisipasi milenial adalah menonton, membaca dan mencari informasi politik dibanding dengan partisipasi yang melibatkan orang lain seperti berinteraksi dan memengaruhi orang untuk memilih calon tertentu. Selain itu, banyaknya studi partisipasi politik di Indonesia juga pada umumnya fokus terhadap perilaku memilih (voting) dengan unit analisa masyarakat dari berbagai tingkatan umur (Hendrik, 2010). Namun beberapa dari mereka memberi batasan, misalnya mengambil unit analisa pemilih pemula (Akhrani, Imansari, \& Faizah, 2018; Fitriah, 2014) atau membatasinya dengan menguji hubungan antara efikasi dengan partisipasi politik (Matulessy, 2013). Studi yang terbaru terkait partisipasi politik juga mengambil peran penggunaan sosial media dalam hubungannya dengan partisipasi politik offline (Morissan, 2014; Kuncoro, 2018; Ratnamulyani \& Maksudi, 2018) dan online (Laksmitha \& Susanto, 2019; Yolanda \& Halim, 2020).

Meskipun demikian, banyaknya literatur terkait partisipasi politik di Indonesia tidak menjelaskan proses mekanisme dari penggunaan media sosial terhadap partisipasi politik. Sebagaimana studi Yamamoto, Nah dan Bae (2019) pengaruh media sosial terhadap partisipasi politik didasarkan pada informasi politik dan heterogenitas diskusi online atau dengan kata lain media sosial tidak memberikan sumbangan secara langsung (direct) terhadap partisipasi politik (Kuncoro, 2018; Weeks, Lane, Kim, Lee, \& Kwak, 2017). Penggunaan media sosial selain memungkinkan untuk memobilisasi publik yang tersebar secara geografis, juga memberikan cara baru bagi keterlibatan warga negara.

Studi terbaru terkait pernggunaan media sosial dan partisipasi politik dilakukan oleh Johannes Knoll, Jorg Matthes dan Raffael Heiss (2018) yang membedakan partisipasi offline dengan online. Partisipasi offline yang dimaksud berupa partisipasi konvensional dan non-konvensional sebagaimana diungkapkan oleh para teoritis partisipasi politik sebelumnya (Mujani, Liddle, \& Ambardi, 2012) sedangkan partisipasi online yang dimksud Knoll, dkk seperti membuat blog, petisi online, like dan komentar di platform media sosial tidak mendapat banyak perhatian. Selain itu Knoll, dkk bahkan membedakan partisipasi online rendah (low) dan tinggi (high) serta partisipasi offline rendah (low) dan tinggi (high), pada tabel.1: 
Tabel.1 Model Partisipasi Politik Offline dan Online

\begin{tabular}{|l|l|l|}
\hline \multirow{3}{*}{ Offline } & Partisipasi Rendah & Partisipasi Tinggi \\
\cline { 2 - 3 } & $\begin{array}{l}\text { Menampilkan atribut kampanye (stiker, } \\
\text { poster, pin, dsb.) }\end{array}$ & $\begin{array}{l}\text { Mengikuti kegiatan pertemuan (rapat dewan } \\
\text { kota, dsb.) }\end{array}$ \\
\cline { 2 - 3 } & Menandatangani petisi & Mengikuti kegiatan demonstrasi \\
\cline { 2 - 3 } & $\begin{array}{l}\text { Mengingatkan individu lain untuk } \\
\text { menggunakan hak suaranya }\end{array}$ & Berkomunikasi dengan kandidat politik \\
\cline { 2 - 3 } Online & $\begin{array}{l}\text { Memberi “like" sebagai tanda setuju pada } \\
\text { laman media sosial kandidat politik atau } \\
\text { gerakan sosial }\end{array}$ & Mengirim surel ke politisi \\
\cline { 2 - 3 } & $\begin{array}{l}\text { Menyebarkan informasi politik ke orang } \\
\text { lain }\end{array}$ & Membuat tulisan politik di situs blog \\
\cline { 2 - 3 } & $\begin{array}{l}\text { Memberi komentar politik singkat pada } \\
\text { laman media sosial }\end{array}$ & Terlibat dalam diskusi politik \\
\cline { 2 - 2 } & Membuat grup politik di lingkup media sosial \\
\hline
\end{tabular}

Sumber: (Jonathan., Matthes \& Heis.2018)

Knoll, dkk juga mewarkan kerangka pengujian Model Partisipasi Politik Media Sosial (Social Media Political Participation Model/SMPPM) untuk menguji pengaruh penggunaan media sosial terhadap partisipasi politik di Indonesia. Seperti halnya Kuncoro (2018) dan Wee, dkk (2017), menurut Knoll, dkk pengaruh penggunaan media sosial atau Social Media Use (SMU) terhadap partisipasi politik (PP) tidak langsung tetapi melalui sejumlah tahapan yang disebut dengan "mekanisme psikologis". Selain itu kerangka Knoll, dkk juga belum banyak diuji pada konteks Generasi Milenial di Indonesia, sebagaimana menurut Plutzer (2002) keterlibatan politik di masa remaja dan dewasa merupakan prediktor yang kuat untuk memperdiksi keterlibatan politik di masa depan.

Penelitian ini akan menggunakan Model Partisipasi Politik Media Sosial (Social Media Political Participation Model) dari Knoll, dkk (2018) spesifik di kalangan anak muda atau milenial. Teori SMPPM yang ditawarkan oleh Knoll, dkk (2016) menjelaskan adanya proses mekanisme psikologis yang dibagi ke dalam empat tahap yakni: Pra-keterpaparan (pre-exposure). Keterpaparan (exposure), Penerimaan (reception) dan kondisi tindakan (behavioral situation). Media sosial sebagai basis informasi berada pada tahapan pertama dan kedua dalam teori Knoll, sedangkan tahapan ketiga adalah proses pertimbangan individu terhadap informasi dan pada tahapan terakhir media sosial berfungsi sebagai sarana partisipasi politik. Selain itu, kebaruan (novelty) ilmiah dari penelitian ini juga akan mengambil spesifik keterpaparan konten tagar \#2019GantiPresiden yang dalam rentang waktu 1 Januari - 5 Desember 2018 tagar \#2019GantiPresiden telah di kutip oleh 6.966.044 orang/akun (Drone Emprit, 2018).

Literatur sebelumnya menunjukan banyak dari ilmuwan yang menganggap tagar berpengaruh besar terhadap partisipasi politik (Jenkins, 2016; Sloam, 2018; Barisione, Michailidou, \& Airoldi, 2017). Selain itu tagar juga merupakan salah satu bentuk dari viralitas yang dikemukakan oleh sejumlah ilmuwan (Castells, 2012; Nahon \& Hemsley, 2013) sebagai cara baru keterlibatan warga negara pada era digital yang ditentukan oleh kecepatan penyebaran informasi, jangkauan dalam kuantitas jumlah yang terpapar konten dan jarak yang ditempuh informasi. Inti dari konsep viralitas adalah kapasitas invidu dan organisasi untuk berbagi informasi dan memobilisasi secara kolektif serta kemampuannya dalam menghubungkan pesan ke beragam jaringan.

Melanjutkan studi viralitas, para ilmuwan spesifik mengkaji penggunaan tagar (hashtag) dalam mempengaruhi viralitas (Gao, 2016; Small, 2011; Zamir, 2015). Menurut Gao (2016) fungsi penggunaan tagar yaitu sebagai "penggerak perhatian" (attention mobilizer). Selain itu visibilitas dari tagar juga penting untuk mencapai kekuatan simbolis, karena memfasilitasi penyebaran informasinya dalam skala besar dan cepat (Castells, 2012). Studi Lotan, Graeff, Annany, Gaffney dan Pearce (2011) menemukan bahwa peran tagar \#sidibouzid di media sosial terutama Twitter memainkan peranan dalam "Arab Spring" di Tunisia dan Mesir. Sementara itu, studi Zamir (2015) juga menemukan hal serupa yakni tagar \#Shahbag berperan dalam unjuk rasa di Bangladesh.

Adapun tagar yang akan diuji dalam penelitian ini adalah \#2019GantiPresiden. Berdasarkan survei yang dilakukan oleh Lingkaran Survei Indonesia terhadap 1200 responden pada periode 28 Juni - 5 Juli 2018 menunjukan bahwa publik semakin menyukai dan menerima hashtag tersebut. Pasalnya pada survei sebelumnya bulan Mei tingkat kesukaan atau penerimaan responden sebesar 49,80\% sedangkan pada bulan Juli mencapai 54,4\% (Rachman, 2018). Meski demikian, pengaruh dari tagar 
\#2019GantiPresiden belum sepenuhnya diuji pengaruhnya terhadap partisipasi politik. Oleh karena itu, dalam penelitian ini tagar \#2019GantiPresiden dapat berperan sebagai basis informasi dikarenakan viralitasnya menjelang pemilihan umum presiden 2019 sekaligus menguji kemampuan tagar dalam mempengaruhi partisipasi politik Generasi Milenial Indonesia, adapun hipotesis dalam penelitian ini adalah:

H1: Tagar \#2019GantiPresiden di Facebook, Twitter dan Instagram berpengaruh terhadap partisipasi politik milenial DKI Jakarta pada pemilihan umum presiden tahun 2019 baik online maupun offline.

H0: Tagar \#2019GantiPresiden di Facebook, Twitter dan Instagram tidak berpengaruh terhadap partisipasi politik milenial DKI Jakarta pada pemilihan umum presiden tahun 2019 baik online maupun offline

\section{METODE PENELITIAN}

Penelitian ini termasuk ke dalam penelitian eksplanatoris (explanatory research). Dilihat dari jenis data yang dikumpulkannya, penelitian ini adalah penelitian kuantitatif, untuk mengetahui pengaruh variabel bebas terhadap variabel terikat dalam penelitian ini. Pengumpulan data primer dilakukan melalui kuesioner sedangkan dan data sekunder dengan studi pustaka. Dalam menguji hipotesis penelitian maka dilakukan sejumlah pengujian yang terbagi menjadi ke dalam beberapa tahapan yakni pengujian terhadap kuisioner (Uji Validitas dan Reliabilitas), gambaran umum responden (statistik deskriptif), uji hubungan dan pengaruh variabel bebas terhadap variabel terikat. Variabel bebas dalam penelitian ini terdapat tiga yakni keterpaparan tagar \#2019GantiPresiden di Facebook (X1), keterpaparan tagar \#2019GantiPresiden di Instagram (X2) dan keterpaparan tagar \#2019GantiPresiden di Twitter (X3). Sedangkan varibel terikat terdiri dari empat yaitu Y1: online partisipation (low), Y2: online partisipation (high), Y3: offline partisipation (low) dan Y4: offline partisipation (high).

Objek dalam penelitian ini adalah penggunaan media sosial oleh generasi milenial. dalam penelitian ini tidak ada data terkait populasi milenial DKI Jakarta yang menggunakan media sosial dengan pasti. Selain itu data yang ada memiliki kelemahan dikarenakan kemungkinan beberapa orang memiliki dua atau lebih akun dalam satu platform media sosial. Oleh karenanya yang dimaksud dengan populasi dalam penelitian ini, sebagaimana menurut Badan Pusat Statistik (BPS) yakni milenial DKI Jakarta yang lahir pada rentang tahun 1980 sampai 2000 atau berusia 19-39 pada tahun 2019. Berdasarkan sampling diambil 399,95 atau dibulatkan menjadi 400 orang milenial DKI Jakarta. Populasi milenial di DKI Jakarta (usia rentang 19-39) pada tahun 2019 berjumlah 3.358.515, diantaranya 1.663 .977 laki-laki dan 1.694 .538 perempuan. Responden dalam penelitian ini terdiri dari 400 orang yang tersebar di 6 Kota administrasi dan 40 kecamatan di DKI Jakarta. Penelitian ini menggunakan teknik multistage cluster random sampling sehingga responden dipilih berdasarkan kluster yang sebelumnya sudah ditentukan sehingga sebaran responden lebih proporsional, diantaranya: $22 \%$ responden berasal dari Jakarta Barat, 10\% dari Jakarta Pusat, 22,2\% dari Jakarta Selatan, 27\% dari Jakarta Timur, 17,2\% dari Jakarta Utara dan 0,3\% dari Kepulauan Seribu. Berikutnya teknik penarikan sampel yang sama juga digunakan untuk menentukan responden berdasarkan kategori Gender (laki-laki $50 \%$ dan Perempuan 50\%), Agama (Islam 90\%, Protestan dan Katolik 6,2\%, lainnya 3,8\%) dan Usia (19-20 tahun 20\%, 21-29 tahun 41,7\% dan 30-39 tahun 38,3\%).

\section{HASIL DAN PEMBAHASAN}

Pengaruh antara variabel bebas $(\mathrm{X} 1, \mathrm{X} 2, \mathrm{X} 3)$ terhadap variabel terikat (Y1, Y2, Y3, Y4) diuji melalui analisis regresi linier sederhana. Berdasarkan hasil olah data melalui aplikasi Statistikal Product and Service Solution (SPSS) ditemukan persamaan regresi antara keterpaparan tagar \#2019GantiPresiden di Facebook (X1), Instagram (X2) dan Twitter (X3) terhadap partisipasi politik online (low) yaitu Y1=2,674 +0,236 (X1) +0,310 (X2) + 0,327(X3). Nilai a (2,674)atau angka konstan mempunyai arti bahwa jika tidak terjadi keterpaparan tagar \#2019GantiPresiden (X) maka nilai konsisten partisipasi politik online (low) atau Y1 sebesar 2.674. Dengan kata lain setiap kenaikan 1\% keterpaparan informasi tagar \#2019GantiPresiden di Facebook maka partisipasi politik Online (low) meningkat sebesar 0,236, sedangkan keterpaparan di Instagram meningkatkan partisipasi online (low) sebesar 0,310 dan keterpaparan di Twitter meningkatkan partisipasi online (low) sebesar 0,327. Adapun terhadap partisipasi online (high) persamaan regresi yang ditemukan adalah Y2 $=2,058+0,777(\mathrm{X} 1)+$ 
$0,639(\mathrm{X} 2)+0,631(\mathrm{X} 3)$, terhadap partisipasi offline (low) $\mathrm{Y} 3=3,115+0,209(\mathrm{X} 1)+0,175(\mathrm{X} 2)+$ $0,197(\mathrm{X} 3)$ dan terhadap partisipasi offline (high) $\mathrm{Y} 3=3,953+0,113(\mathrm{X} 1)+0,142(\mathrm{X} 2)+0,123(\mathrm{X} 3)$.

Pengaruh antara variabel bebas dan terikat diuji berdasarkan nilai signikansi (Sig.) dan t hitung. Apabila nilai Sig. $<0.05$ maka terdapat pengaruh dan H1 diterima sedangkan H0 ditolak. Begitupula jika nilai $\mathrm{t}$ hitung $>\mathrm{t}$ tabel $(2,364624)$ maka terdapat korelasi dan $\mathrm{H} 1$ diterima sedangkan $\mathrm{H} 0$ ditolak. Berikut output SPSS (coefficients):

Tabel.1 Coefficients

\begin{tabular}{|l|c|c|c|c|c|c|c|c|}
\hline \multirow{2}{*}{ Variabel } & \multicolumn{2}{|c|}{ Y1 } & \multicolumn{2}{c|}{ Y2 } & \multicolumn{2}{c|}{ Y3 } & \multicolumn{2}{c|}{ Y4 } \\
\cline { 2 - 9 } & $\mathbf{t}$ & Sig. & t & Sig. & t & Sig. & t & Sig. \\
\hline Facebook & 6,370 & 0,000 & 3,878 & 0,000 & 4,537 & 0,000 & 1,976 & 0,049 \\
\hline Instagram & 6,400 & 0,000 & 3,772 & 0,000 & 3,795 & 0,000 & 2,571 & 0,011 \\
\hline Twitter & 4,164 & 0,000 & 3,898 & 0,000 & 2,443 & 0,018 & 2,376 & 0,019 \\
\hline
\end{tabular}

Berdasarkan output di atas diketahui keterpaparan informasi tagar \#2019GantiPresiden di Facebook tidak berpengaruh terhadap partipasi politik offline (high) karena nilai t hitung 1,974 < 2,364624 atau dengan kata lain H1 ditolak dan H0 diterima. Selain itu seluruhnya memiliki pengaruh baik dengan pengujian nilai Sig. maupun dengan t hitung artinya H1 diterima dan H0 ditolak., berikut juga varibel X1 tetap berpengaruh terhadap Y1, Y2 dan Y3. Berikutnya untuk mengetahui besarnya pengaruh variabel X terhadap variabel Y melalui output SPSS bagian model summary sebagai berikut:

Tabel.3 Model Summary

\begin{tabular}{|l|l|l|}
\hline Model Paritisipasi & \multicolumn{1}{|c|}{ R } & \multicolumn{1}{c|}{ R Square } \\
\hline Online Partisipation (Low) & 0,378 & 0,143 \\
\hline Online Partisipation (High) & 0,500 & 0,250 \\
\hline Offline Partisipation (Low) & 0,375 & 0,140 \\
\hline Offline Partisipation (High) & 0,211 & 0,045 \\
\hline
\end{tabular}

Dari output di atas diketahui nilai R Square pada partisipasi online (low) sebesar 0,143 artinya seluruh seluruh variabel X atau keterpaparan informasi tagar \#2019GantiPresiden di Facebook, Instagram dan Twitter berpengaruh terhadap partisipasi online (low) sebesar 14,3\%. Sedangkan 85,7\% partisipasi online (low) dipengaruhi variabel yang tidak diteliti atau selain keterpaparan informasi tagar \#2019GantiPresiden di Facebook, Instagram dan Twitter. Begitupula seluruh varibel X berpengaruh terhadap partisipasi online (high) sebesar 25\% dan terhadap partisipasi offline (low) sebesar $14 \%$. Sedangkan untuk untuk partisipasi offline (high) peneliti membuang variabel keterpaparan informasi tagar \#2019GantiPresiden di Facebook (X1) dan menyisakan X2 (Instagram) dan X3 (Twitter) untuk diuji ulang, adapun hasilnya pengaruh X2 dan X3 terhadap partisipasi offline (high) sebesar 5,3\%, naik dibanding sebelum diuji ulang $(4,5 \%)$.

Pengaruh secara rinci dijelaskan melalui 4 tahapan yang dikemukakan oleh Knoll, dkk (2018) sekaligus menguji proposisi yang diajukan. Namun terlebih dahulu akan dideskripsikan karakteristik responden sebagai gambaran umum responden ataua dalam hal ini Milenial DKI Jakarta. Mayoritas responden dalam penelitian ini mengaku berasal dari Suku Jawa (48\%), Betawi (31,5\%) dan Sunda $(9,5 \%)$. Sedangkan responden yang lainnya tersebar berasal dari beragam suku seperti Suku Batak $(2,8 \%)$, Suku Tionghoa (2,5\%), Suku Minangkabau (2,0\%), Suku Melayu (1,7\%), Suku Madura (0,5\%), Suku Bugis $(0,3 \%)$ dan lainnya $(1,2 \%)$. , pendidikan terakhir responden paling banyak adalah Sekolah Menengah Atas (SMA) yaitu sebanyak 53,1\% disusul dengan lulusan D4/S1/S2/S3 sebanyak 21,3\%, lulusan D1/D2/D3 sebanyak 13,8\%, Sekolah Menengah Pertama (SMP) sebanyak 9\% dan diantaranya terdapat juga responden lulusan Sekolah Dasar (SD) sebanyak 2,3\% dan mengaku tidak sekolah sebanyak $0,5 \%$.

$52,1 \%$ atau setengahnya dari 400 responden sudah memiliki pekerjaan tetap, diantaranya paling banyak responden bekerja karyawan swasta $(28,3)$. Lalu terdapat juga $21,5 \%$ yang berkerja sebaga wirausaha/pedagang, 2\% sebagai Aparatur Sipil Negara (ASN/PNS) dan 0,2\% bekerja profesional sebagai Dokter, Advokat, dll. Selain itu 47,9\% bukan perkerja tetap, diantaranya 22,8\% masih menempuh pendidikan sebagai pelajar/mahasiswa, 15,3\% memilih tidak bekerja dan menjadi Ibu Rumah Tangga sedangkan 9,8\% tidak memiliki pekerjaan atau tidak tetap. Selain itu, mayoritas respon 
yaitu sebanyak 75,8\% dalam penelitian ini memiliki gaji/penghasilan dibawah 5 juta sedangkan 24,2\% sisanya berpenghasilan diatas 5 juta per bulan. Bahkan 1,3\% responden berpenghasilan 20-50 juta perbulan dan $1 \%$ lebih dari 50 juta dalam sebulan. Berikutnya terkait 4 tahapan "mekanisme psikologis" seperti: pres-exposure, exposure, reception dan behavioral situation.

\section{Pre-exposure}

Pada tahapan pertama, Knoll, Matthes, \& Heiss (2018) menjelaskan bahwa penggunaan media didasarkan pada kebutuhan dan motivasi individu. Yang dimaksud dengan kebutuhan dalam menggunakan sosial media adalah kebutuhan biologi dan psikologi atau yang kemudian dibagi menjadi dua, yaitu disposisi pribadi (kepribadian, emosi, usia dan preferensi) dan disposisi situasional (lingkungan dan perkembangan teknologi). Satu proposisi yang diajukan Knoll, Matthes, \& Heiss (2018) pada tahapan ini yaitu (P1) ": motivasi untuk menggunakan media sosial ditentukan oleh disposisi pribadi dan situasional". Kebutuhan tersebut didasarkan pada motivasi seseorang, diantaranya untuk (1) informasi, (2) identitas personal, (3) intertaiment, (4) interaksi sosial, dan (5) ekspresi.

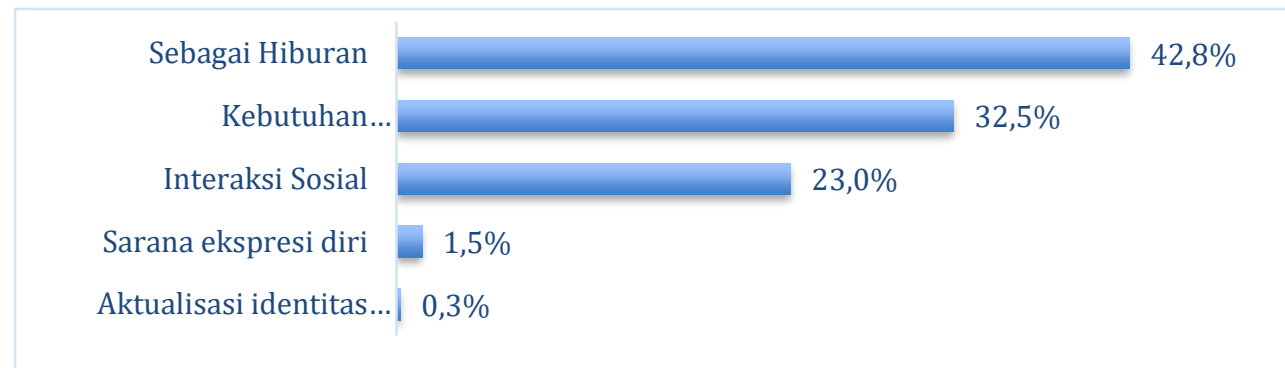

\section{Fig.1 Motivasi Milenial dalam Menggunakan Sosial Media}

Berdasarkan grafik di atas, $42 \%$ alasan menggunakan sosial media adalah untuk mencari konten sosial dan hiburan atau intertaiment, $32,5 \%$ di antaranya beralasan untuk kebutuhan informasi dan $23 \%$ untuk interaksi sosial. Adapun ketika ditanya terkait informasi yang dibutuhkan, $72 \%$ dari keseluruhan responden mencari informasi terkait sosial dan hiburan. Sisanya, 15,3\% terkait informasi ekonomi dan bisnis, $5 \%$ politik dan pemerintahan, $4,8 \%$ terkait topik keagamaan dan lainnnya (3\%).

Terkait faktor lingkungan sosial (masyarakat/komunitas), responden mengaku hal tersebut biasa saja dan kurang berpengaruh $(40,6 \%)$ terhadap aktivitasnya di media sosial, bahkan persentase yang hampir sama $(40,8 \%)$ dari responden mengaku dirinya tidak terpengaruh sama sekali oleh lingkungan sosial. Hanya 13,5\% dari responden yang mengaku terpengaruh dari lingkungan sosial, bahwa 5,3\% mengaku sangat terpengaruh.

Adapun media sosial yang sering digunakan oleh responden adalah Instagram (36,5\%), Facebook $(30,8 \%)$, Twitter (2,8\%), ketiganya (3\%) dan lainnya (27\%). Spesifik terkait pengguna instagram, $44 \%$ dari responden setiap hari menggunakan instagram dan hanya $0,7 \%$ yang mengaku memiliki akun Instagram namun tidak pernah sama sekali menggunakannya. Selain itu, 11,8\% dari responden menyatakan bahwa dirinya tidak pernah mencari informasi yang sedang viral atau ramai diperbincangkan sedangkan $71,9 \%$ dari responden mengikuti atau sengaja mencari informasi viral minimal seminggu sekali di sosial media serta hanya $16,3 \%$ diantara responden yang mencari informasi viral setiap hari.

\section{Exposure}

Pada tahap kedua, individu yang menggunakan media sosial terbagi menjadi dua yakni pengguna aktif dan pasif. Maksudnya pengguna yang aktif mencari konten politik akan terpapar informasi dengan sengaja (intentional exposure) sedangkan pengguna yang pasif juga dapat terpapar konten politik secara tidak sengaja (incidental exposure). Terdapat 4 proposisi yang diajukan Knoll, Matthes, \& Heiss (2018) pada tahap ini, namun hanya dua yang digunakan dalam penelitian ini yaitu: (P2) informasi politik maupun motivasi ekspresi politik akan bekerja pada pengguna media sosial yang memang mengarah pada kondisi keterpaparan yang disengaja karena mencari konten informasi politik, (P3) motivasi 
hiburan, motivasi interaksi sosial, motivasi informasi nonpolitis, motivasi ekspresi nonpolitis, akan bekerja pada pengguna media sosial non politis, sehingga konten politik yang mengarah padanya adalah keterpaparan yang tidak disengaja.

Pada tahap sebelumnya mayoritas responden menggunakan media sosial bukan untuk mencari informasi atau berita politik melainkan intertaiment. Artinya mayoritas responden tidak sengaja mencari informasi politik di media sosial. Bahkan $17,5 \%$ responden mengaku tidak pernah sama sekali mendapatkan informasi politik.

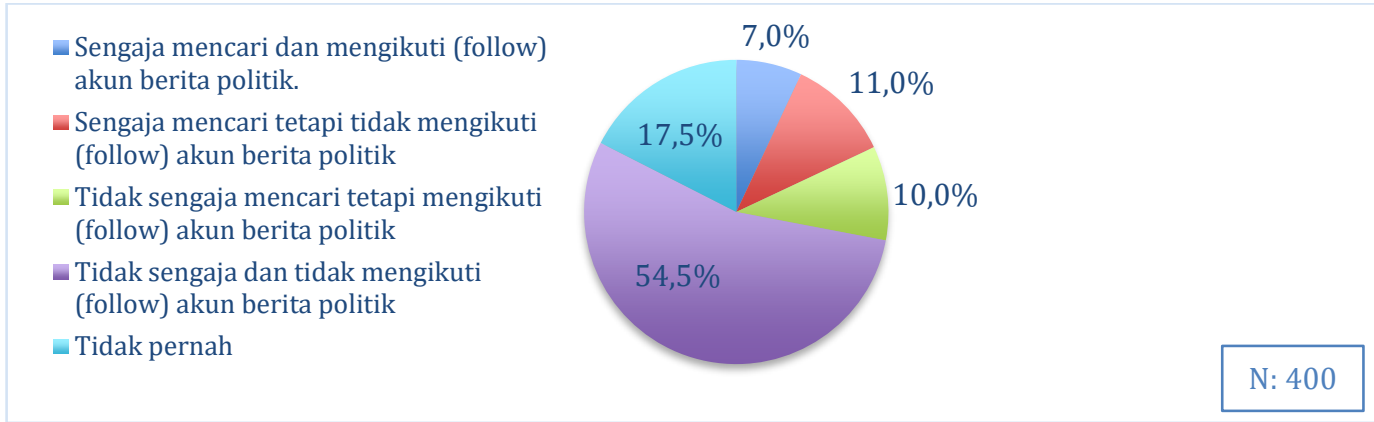

Fig.2 Motivasi Milenial dalam Menggunakan Sosial Media

Grafik di atas menunjukkan bahwa hanya $18 \%$ dari total responden yang pernah dengan sengaja mencari informasi politik di media sosial, $7 \%$ di antaranya karena mengikuti (follow) akun berita politik dan $11 \%$ sengaja tetapi tidak mengikuti akun berita politik. Sedangkan $64,5 \%$ dari total responden mengaku mendapatkan informasi politik tanpa disengaja, 10\% di antaranya karena mengikuti akun berita politik sedangkan $54,5 \%$ justru mendapatkan informasi politik tanpa mengikuti akun berita politik. Adapun dari total responden yang pernah mendapatkan informasi politik $(82,5 \%)$ mengaku lebih banyak mendapatkan informasi politik dari media sosial $(42,3 \%)$, televisi $(31,4 \%)$ dan media online $(1,5 \%)$. Sedangkan sisanya mendapatkan informasi politik dari media cetak $(0,2 \%)$, komunitas sosial/masyarakat $(0,8 \%)$ dan lainnya $(6,2 \%)$. Spesifik terkait tagar \#2019GantiPresiden, mayoritas responden mengaku tahu (cukup tahu, tahu dan sangat tahu), sebagaimana grafik berikut:

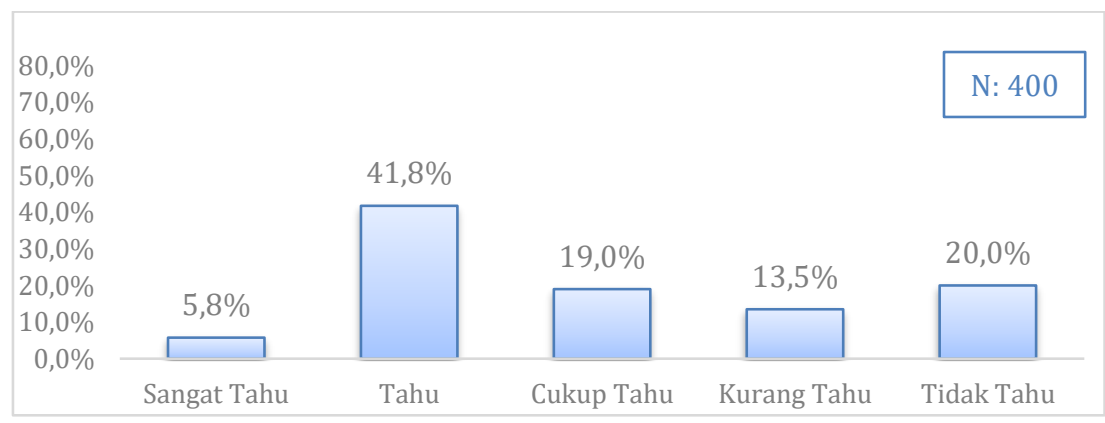

Fig.3 Responden Mengetahui Tagar \#2019GantiPresiden

Berdasarkan grafik di atas, 33,5\% responden mengaku sama sekali tidak tahu dengan tagar \#2019GantiPresiden. Angka yang lebih tinggi yakni 48,3\% responden mengaku sama sekali tidak tahu tagar \#2019TetapJokowi. Adapun dari $66,6 \%$ dari responden yang mengetahui tagar \#2019GantiPresiden, mayoritas mendapatkan informasi tersebut dari media sosial $(45,4 \%)$ dan Televisi $(15,9 \%)$. Selain itu, mereka (32\%) juga mengetahui tagar tersebut sejak tahun 2018 atau lebih dari 4 bulan sebelum pencoblosan atau kurang dari 3 bulan sebelum pencoblosan (30,7\%). Sedangkan 3,7 \% dari responden mengaku tahu tagar \#2019GantiPresiden pada saat hari H pencoblosan. Selain itu mayoritas responden yang tahu informasi tagar \#2019GantiPresiden juga sengaja mencari atau mengikuti informasi tersebut. 

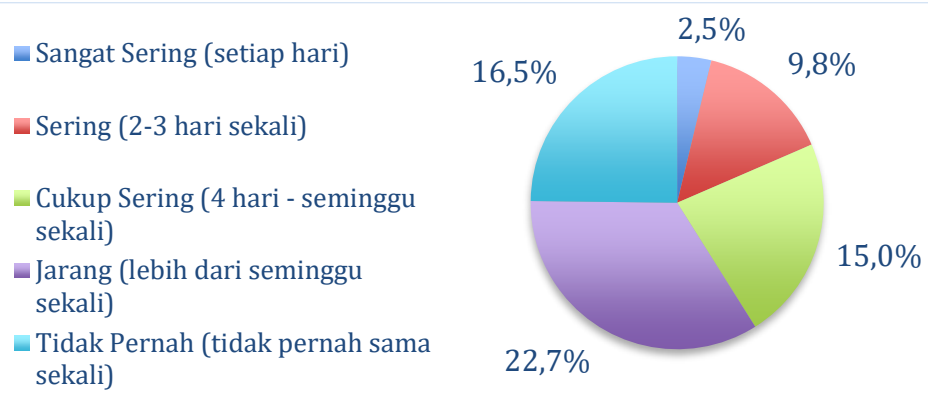

Fig.4 Responden Mengikuti Tagar \#2019GantiPresiden

Grafik di atas menunjukan $16,5 \%$ dari responden yang tahu tetapi tidak mengikuti informasi tagar \#2019GantiPresiden, sisanya sengaja atau mengaku pernah (22,7\%), cukup sering (15\%), sering $(9,8 \%)$ bahkan sangat sering (2,5\%) mengikuti informasi perkembangan tagar \#2019GantiPresiden. Oleh karena itu pada tahapan ini diketahui bahwa mayoritas responden $(82,5 \%)$ yang terpapar informasi politik juga mayoritas $(66,6 \%)$ mengetahui tagar \#2019GantiPresiden dan bahkan sengaja mengikuti informasi tersebut $(64,1 \%)$.

Mengacu pada dua proposisi Knoll, Matthes, \& Heiss (2018) seharusnya 76,5\% yang tidak memiliki motivasi mencari informasi politik dan ekspresi politik terpapar informasi politik dengan tidak sengaja sedangkan Grafik 2 di atas menunjukan hanya $64,1 \%$ dari total responden mengaku mendapatkan informasi politik tidak disengaja dan 35,9\% diantaranya sengaja. Artinya terdapat $12,4 \%$ responden yang tidak memiliki motivasi informasi politik dan ekspresi politik namun sengaja mencari atau terpapar informasi politik. Selain itu, meskipun angka keterpaparan informasi politik yang disengaja kecil $(33,5 \%)$, namun 66,6\% dari total responden mengetahui tagar \#2019GantiPresiden. Dengan kata lain tagar memiliki jangkaun keterpaparan yang melampaui informasi politik itu sendiri atau responden dengan motivasi non-politik dapat terpapar tagar.

\section{Reception}

Tahap ketiga, individu yang terpapar konten politik (baik disengaja maupun tidak) akan mempertimbangkannya berdasarkan tujuan personal. Jika konten politik tersebut relevan dengan tujuannya maka individu tersebut dapat menyatakan dukungannya secara langsung di media sosial (eksplisit) atau diam-diam (implisit). Tetapi jika tidak dianggap relevan maka individu akan mengabaikan informasi tersebut. Tahap ketiga ini juga disebut sebagai disparensi atau munculnya keinginan akan tatanan baru dalam kehidupan bernegara.

Pada tahap ketiga ini penulis mengambil 4 dari 6 yang diajukan Knoll, Matthes, \& Heiss (2018), yaitu: (P6) jika terpapar konten politik, pengguna media sosial akan menilai relevansi konten tergantung pada pesannya, sumber, dan karakteristik jaringan, (P7) jika konten politik dinilai relevan, pengguna membuka diri terhadap konten politik terkait di media lain atau komunikasi antarpribadi, (P12) jika konten politik dinilai tidak tidak dapat dicapai, pengguna tidak menunjukkan peningkatan partisipasi politik. Meskipun pada tahap sebelumnya mayoritas responden sengaja mengikuti informasi tagar \#2019GantiPresiden namun dari total keseluruhan responden penelitian ini, 52,1\% diantaranya kurang sepakat atau tidak sepakat dengan tagar \#2019GantiPresiden, sebagai berikut:

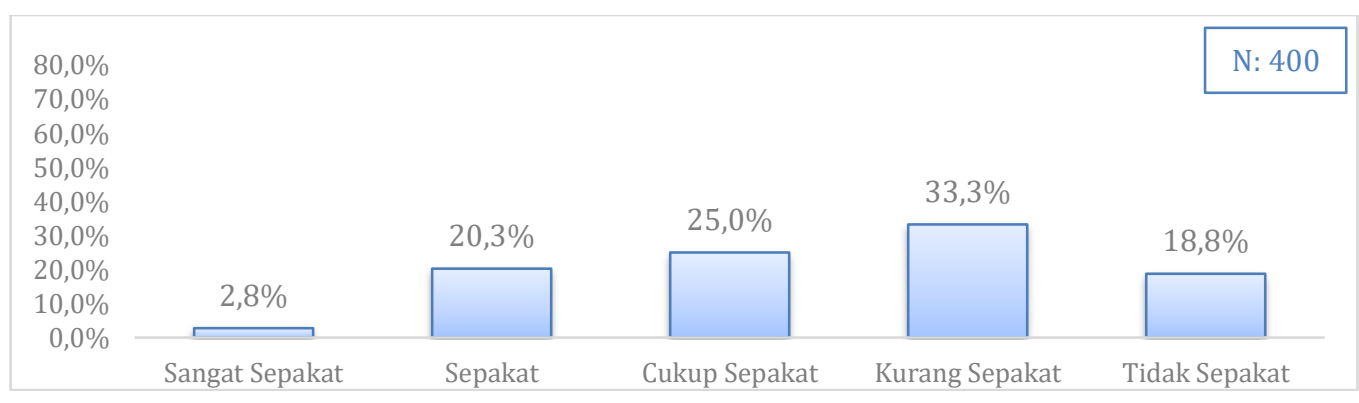

Fig.5 Relevansi Tagar \#2019GantiPresiden 
Berdasarkan tabel di atas 47,9\% responden sepakat dengan tagar \#2019GantiPresiden. Adapun alasannya beragam, dikarenakan tagar\#2019GantiPresiden merupakan hak konstitusional warga negara $(21,9 \%)$, karena memilih pasangan Prabowo Subianto dan Sandiaga Uno pada pemiihan umum presiden 2019 (16,8\%), karena menganggap petahana atau Joko Widodo gagal memimpin Indonesia sehingga perlu dilakukan pergantian $(7,5 \%)$ serta karena ketidaksukaan responden terhadap pasangan Joko Widodo-Ma'ruf Amin atau asal bukan Jokowi $(1,8 \%)$. Adapun responden yang kontra dengan tagar \#2019GantiPresiden mayoritas mengerti $(55,4 \%)$ Sedangkan sisanya menolak karena tidak mengerti maksud dari tagar \#2019GantiPresiden (23,2\%). Meskipun mengerti dengan maksud dari tagar tersebut namun beberapa responden tetap tidak mau ganti presiden/tetap memilih petahana $(13,4 \%)$ atau menolak karena menganggap tagar tersebut terlalu provokatif $(9,8 \%)$ atau karena memang tidak suka dengan tagar tersebut $(5,7 \%)$.

Meskipun pro-kontranya cukup berimbang namun 75\% dari keseluruhan responden mengaku mengabaikan informasi tagar \#2019GantiPresiden setelah mendapatkannya atau dengan kata lain mayoritas mengekspresikan dengan cara implisit bukan secara langsung menyatakan sikapnya (eksplisit), lihat grafik berikut:

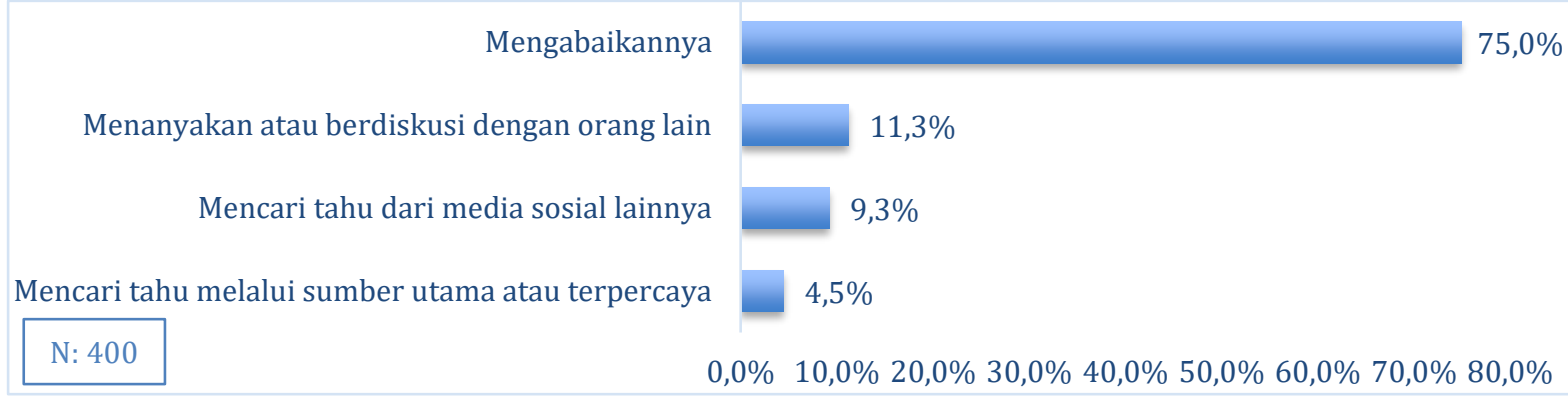

\section{Fig.6 Respon terhadap Tagar \#2019GantiPresiden}

Berdasarkan proposisi 6 dan 7 dan dari grafik di atas maka 25\% responden menganggap informasi \#tagar2019GantiPresiden, 11,3\% diantaranyaberupaya untuk mencari tahu informasi tagar \#2019GantiPresiden ketika pertama kali mendapatkannya dari berbagai sumber seperti media sosial $(9,3 \%)$, bertanya atau berdiskusi dengan orang lain $(11,3 \%)$ atau bahkan berusaha mencari tahu melalui sumber utama/terpercaya $(4,5 \%)$.

Adapun di antara responden yang tidak sepakat dengan tagar \#2019GantiPresiden atau menganggapnya tidak relevan, sebagaimana menurut Knoll, dkk, (Proposisi 12) mayoritas cenderung mengabaikan tagar tersebut $(48,5 \%)$. Adapun penolakan secara eksplisit ditujukan dengan cara memberi tanda tidak suka $(1,2 \%)$, memberi komentar yang berisi kritik $(1,2 \%)$, mengunggah tulisan (opini) pribadi yang menyatakan ketidaksepakatannya $(0,7 \%)$ atau bahkan memblokir berita/akun yang menyebarkan infromasi tagar \#2019GantiPresiden $(0,3 \%)$.

\section{Behavioral Situation}

Kemudian tahap terakhir adalah kondisi dimana individu bertindak berdasarkan informasi yang diterima dari media sosial. Apabila informasi yang diterima dianggap tidak relevan maka individu tidak akan berpartisipasi. Tetapi apabila informasi dianggap relevan dan dieksplisitkan maka individu cenderung berpartisipasi tinggi, sedangkan jika dianggap relevan tetapi diimplisitkan maka individu cenderung berpartisipasi rendah. Adapun proposisi yang diuji dalam tahapan ini hanya 3 dari 16 proposisi yang diajukan Knoll, Matthes, \& Heiss (2018), yaitu: (P18) Jika tujuan nondominan dinilai konsisten dengan pencapaian tujuan yang lebih dominan, pengguna media sosial melakukan partisipasi politik dengan usaha rendah, (P21) Jika pesan tidak mengandung informasi yang terkait dengan tujuan partisipatif, pengguna tidak menunjukkan peningkatan partisipasi politik dan, (P24) partisipasi politik dengan upaya rendah selanjutnya dapat mempengaruhi partisipasi politik dengan upaya tinggi

Adapun dari total responden yang menganggap informasi tagar \#2019GantiPresiden relevan $(47,9 \%)$ memiliki respon dan sikap yang beragam. Penulis mengkategorikan sikap responden sesuai 
dengan kategorisasi Knoll, dkk yaitu partisipasi online (low \& high) dan partispasi offline (low dan high), sebagai berikut:

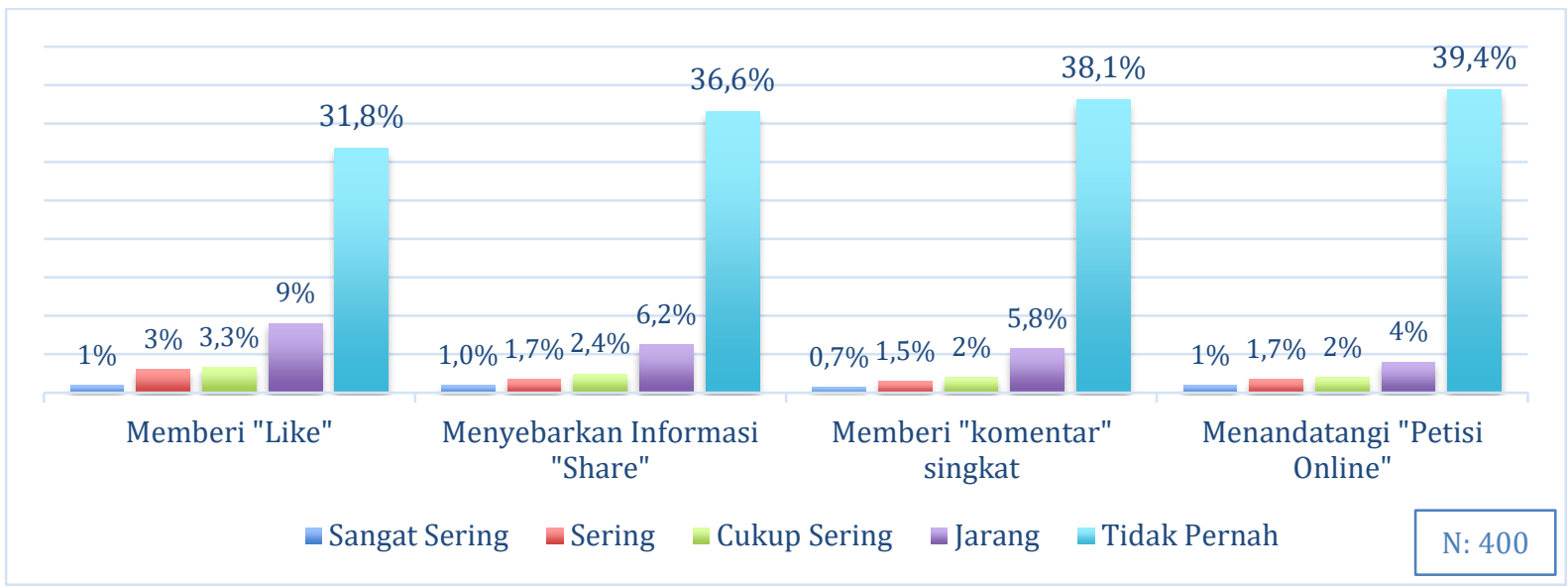

Fig.7 Bentuk Partisipasi Online (Low)

Grafik di atas menunjukan pengaruh keterpaparan tagar \#2019GantiPresiden terhadap bentuk partisipasi online (low). Apabila jika dikategorikan menjadi dua yakni pernah dan tidak pernah maka sikap responden yang sepakat dengan tagar \#2019GantiPresiden melakukan partisipasi online (low) lebih sering dalam bentuk memberi "like" $(16,35 \%)$ pada postingan atau informasi terkait tagar \#2019GantiPresiden terutama di instagram $(65,1 \%)$, facebook $(19 \%)$, twitter $(6,3 \%)$, ketiganya $(1,6)$ dan lainnya (7,9\%). Sama halnya dengan bentuk partisipasi online (low) lainnnya seperti menyebarkan informasi "share" $(11,4 \%)$, memberi komentar $(9,9 \%)$ dan mendatangani petisi online $(8,6 \%)$ juga paling banyak dilakukan melalui media sosial instagram, kemudian Facebook dan terakhir Twitter. Adapun rata-rata responden sepakat dengan tagar \#2019GantiPresiden dan melakukan partisipasi online (low) seperti "like/share/komentar/petisi online" adalah 11,56\% sedangkan rata-rata yang sepakat tapi tidak pernah melakukan partisipasi online (low) adalah $36,44 \%$.

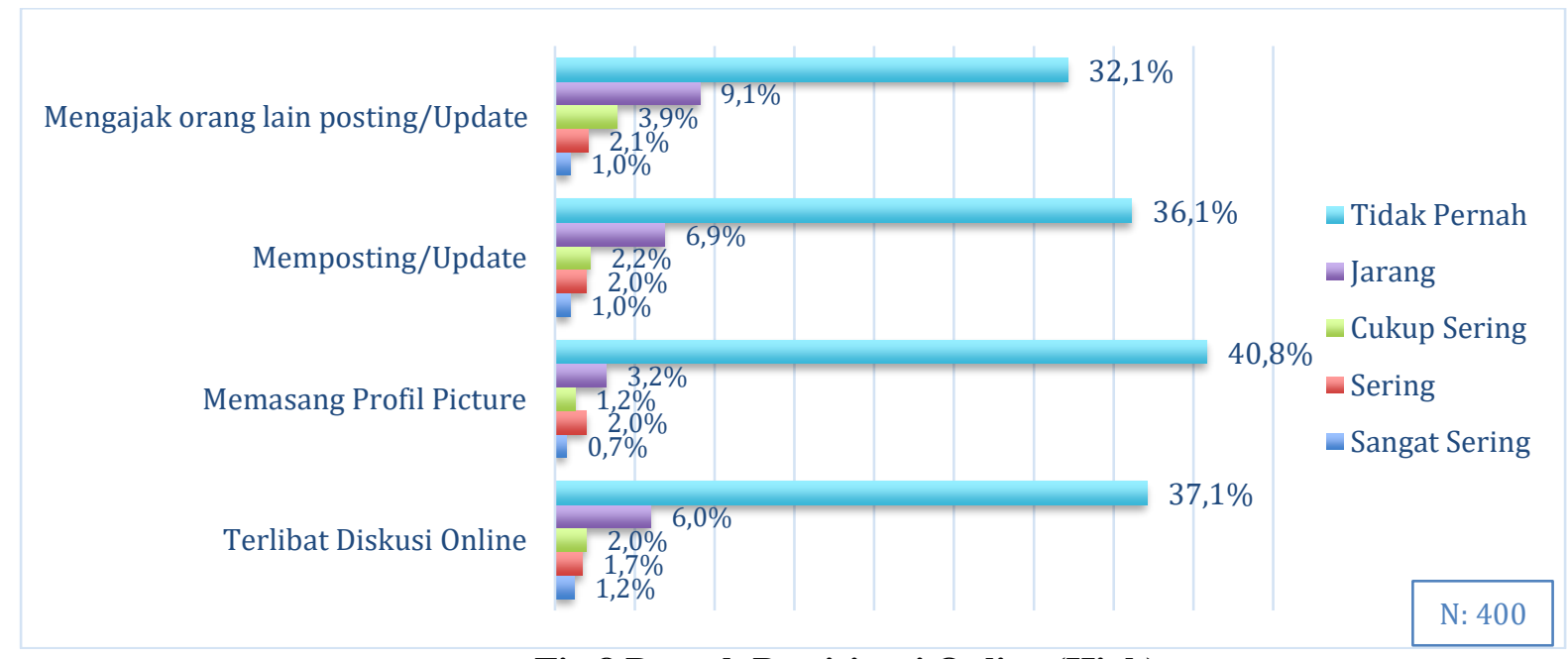

Fig.8 Bentuk Partisipasi Online (High)

Grafik di atas menunjukan pengaruh keterpaparan tagar \#2019GantiPresiden terhadap bentuk partisipasi online (high). Apabila jika dikategorikan menjadi dua yakni pernah dan tidak pernah maka sikap responden yang sepakat dengan tagar \#2019GantiPresiden melakukan partisipasi online (high) lebih sering dalam bentuk mengajak orang lain memposting/update terkait tagar \#2019GantiPresiden di media sosial (16\%), memposting/update sendiri (12\%), terlibat dalam diskusi politik online (10,9\%) dan memasang profile picture di media sosial (7,2\%). Yang menarik dari data di atas terdapat $4 \%$ responden yang tidak pernah memposting tagar \#2019GantiPresiden namun mengajak orang lain 
memposting/mengupdate tagar \#2019GantiPresiden. Adapun posting/update terkait tagar \#2019GantiPresiden paling banyak di lakukan pada media sosial selain Instagram, Facebook dan Twitter yakni Whatsapp (33,3\%), sedangkan 20,6\% responden memposting di Instagram, 22,2\% di Facebook, 8,3\% di Twitter dan ketiganya 5,6\%. Sedangkan diskusi online lebih banyak dilakukan di Instagram (32\%), Facebook (20\%), Twitter (20\%), ketiganya (4\%) dan media yang lainnya (24\%). Adapun rata-rata responden sepakat dengan tagar \#2019GantiPresiden dan melakukan partisipasi online (high) seperti adalah $11,51 \%$ lebih kecil dibanding rata-rata partisipasi online (low), sedangkan ratarata yang sepakat tapi tidak pernah melakukan partisipasi online (high) adalah 36,55\%.

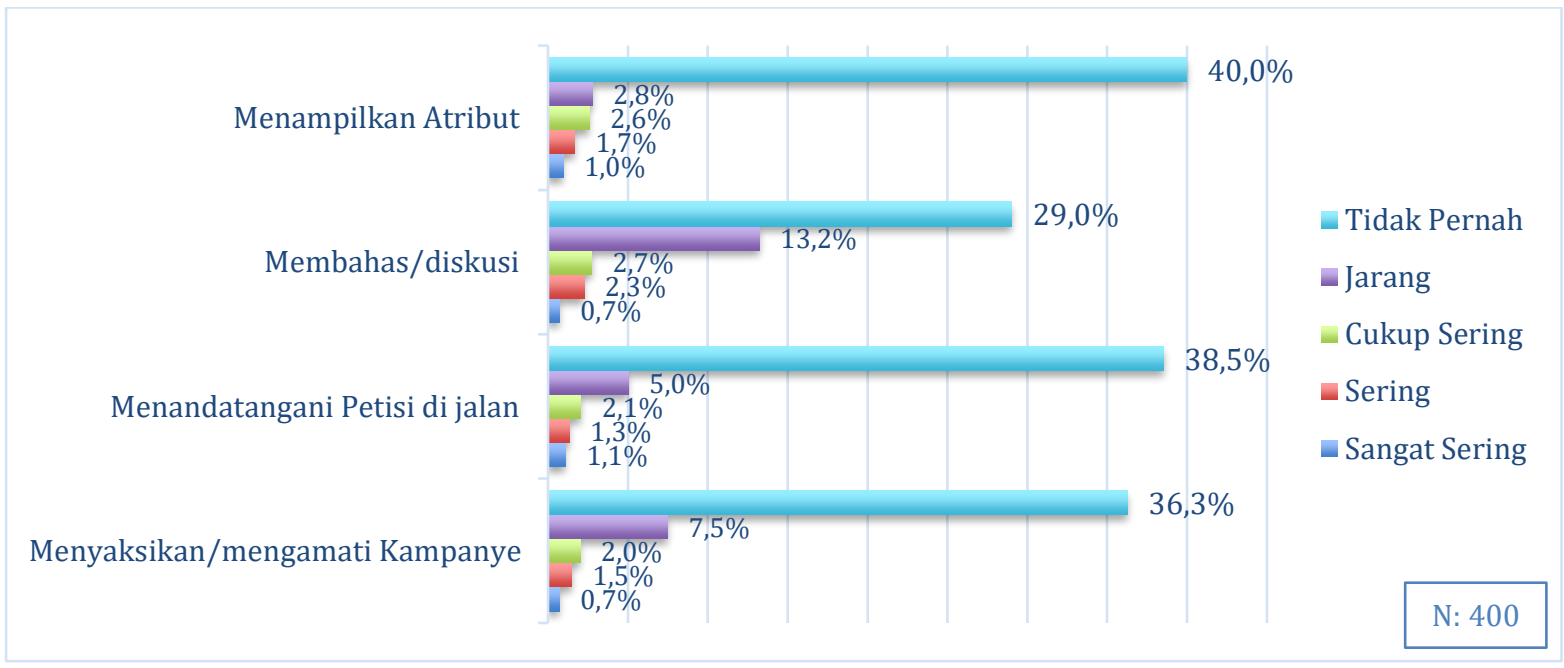

Fig.9 Bentuk Partisipasi Offline (Low)

Grafik di atas menunjukan bentuk partisipasi offline (low), Apabila jika dikategorikan menjadi dua yakni pernah dan tidak pernah maka sikap responden yang sepakat dengan tagar \#2019GantiPresiden melakukan partisipasi online (high) lebih sering dengan cara membahas dan mendiskusikan informasi tagar \#2019GantiPresiden yaitu 19\%, sedangkan yang lainnya seperti menyaksikan dan mengamati kampanye tagar \#2019GantiPresiden sebanyak 11,7\%, mendatangani petisi di jalan sebanyak 9,6\% dan menampilkan atribut kampanye (stiker, poster, pin, dsb) sebanyak $8 \%$. Adapun rata-rata responden sepakat dengan tagar \#2019GantiPresiden dan melakukan partisipasi oflline (low) adalah 12,06 \% sedangkan rata-rata yang sepakat tapi tidak pernah melakukan partisipasi offline (low) adalah 35,96\%.

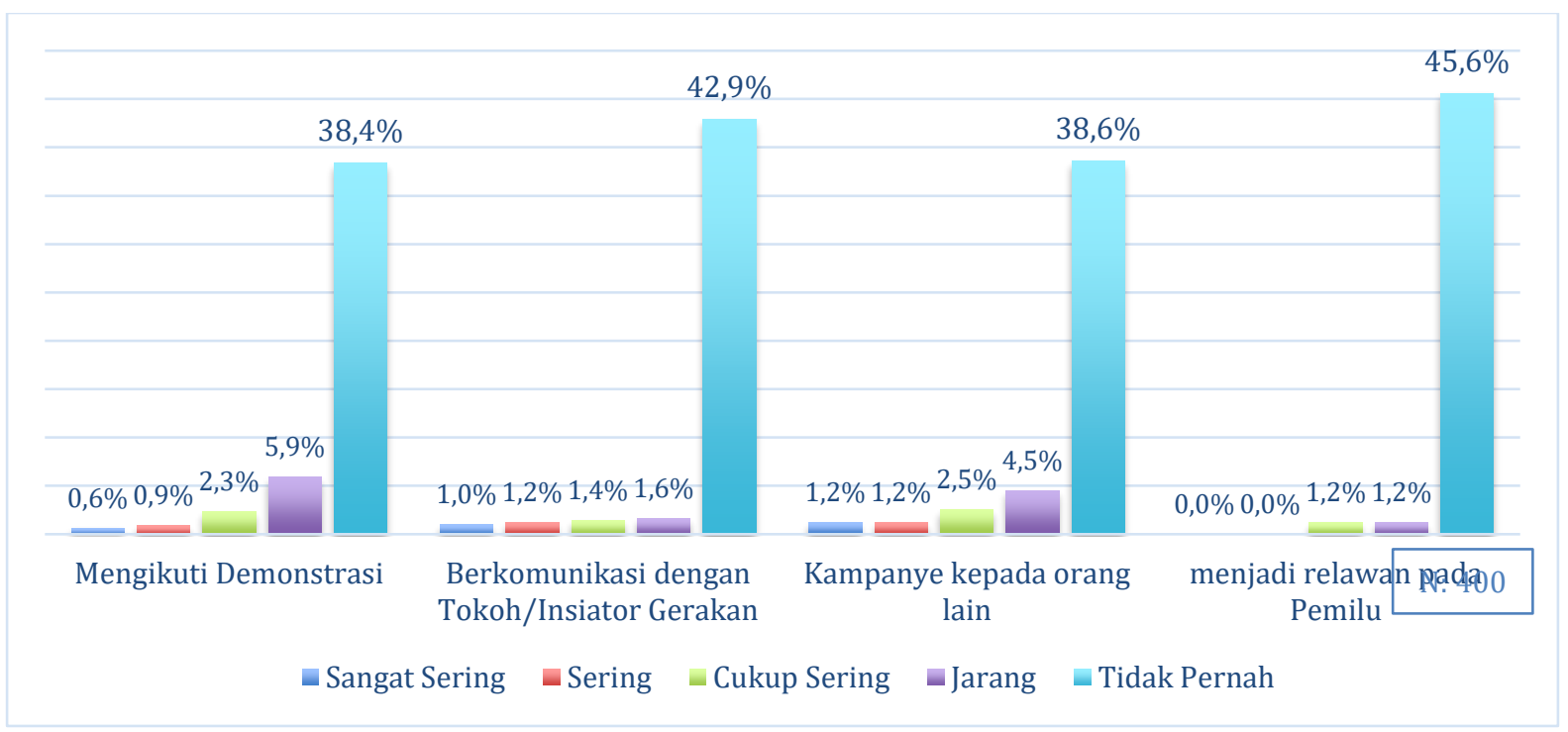

Fig.10 Bentuk Partisipasi Offline (High) 
Grafik di atas menunjukan bentuk terbanyak dari partisipasi offline (high). Apabila jika dikategorikan menjadi dua yakni pernah dan tidak pernah maka sikap responden yang sepakat dengan tagar \#2019GantiPresiden melakukan partisipasi online (high) lebih sering mengikuti kegiatan demonstrasi/kampanye tagar \#2019GantiPresiden (9,7\%) sekaligus mengkampanyekannya kepada orang lain $(9,4 \%)$. Selain itu $5,1 \%$ responden juga mengaku berkomunikasi dengan tokoh atau insiator tagar \#2019GantiPresiden seperti Mardani Ali Sera atau Neno Warisman dan hanya 2,4\% diantara responden yang terlibat menjadi relawan dalam pemilihan umum. Adapun rata-rata responden sepakat dengan tagar \#2019GantiPresiden dan melakukan partisipasi offlline (high) adalah 6,66\% atau jauh lebih kecil dibanding rata-rata partisipasi offline (low), sedangkan rata-rata yang sepakat tapi tidak pernah melakukan partisipasi offline (high) adalah 35,96\%.

Berdasarkan pandangan Knoll, dkk (Proposisi 18) partisipasi online/offline (low) dikarenakan responden tidka memiliki tujuan dominan atas tagar \#2019GantiPresiden, meskipun sepakat namun baginya terdapat tujuan lain yang lebih dominan. Selain itu, proposisi 21 dan 22, menunjukan bahwa peningkatan partisipasi dari "low" menuju "high" terjadi karena informasi tagar \#2019GantiPresiden mengandung tujuan partisipatif. Berdasarkan figur 7 dan 8 rata-rata partisipasi online (low) sedikit lebih kecil dari partisipasi online (high), begitupun figur 9 dan 10 menunjukan hal yang sama atau bahkan rata-rata partisipasi offline (low) jauh lebih dari partisipasi offline (high). Meski begitu rata-rata yang pernah melakukan partisipasi online $(11,53 \%)$ lebih besar dibanding rata-rata partisipasi offline $(9,36 \%)$. Hal ini juga sesuai dengan tabel 3 . Model Summary yang menunjukan bahwa pengaruh konten tagar \#2019GantiPresiden di Facebook, Instagram dan Twitter lebih berpengaruh terhadap partisipasi online dibanding partisipasi offline.

\section{KESIMPULAN}

Berdasarkan uraian di atas maka H1 diterima dan H0 ditolak atau dengan kata lain terdapat pengaruh keterpaparan konten tagar 2019GantiPresiden di Facebook, Instagram dan Twitter dengan partisipasi politik Generasi Milenial DKI Jakarta. Pengaruh yang cukup besar terutama pada partispasi online (Low \& High). Uraian diatas juga menunjukan bahwa rata-rata partisipasi online lebih besar dibanding partisipasi offline, artinya pengaruh tagar \#2019GantiPresiden hanya terhadap partisipasi online saja namun tidak dapat mendorong perubahan besar terhadap rata-rata partisipasi offline. Bahkan keterpaparan tagar \#2019GantiPresiden juga tidak dapat meningkatkan rata-rata responden yang pernah melakukan partisipasi online/offline (low) menuju partisipasi online/offline (high). Hal itu menurut Knoll, dkk (2018) dikarenakan konten tagar \#2019GantiPresiden tidak memiliki tujuan partisipatif dan tidak lebih dominan dibanding tujuan individu meskipun responden tersebut sepakat dengan adanya tagar \#2019GantiPresiden.

\section{REFERENSI}

AKHRANi, L. A., IMANSARI, F., \& FAIZAH. (2018). KePERCAYAAn POLITIK DAN PARTiSPASi POLITIK PEMILIH PEMULA. MEDIAPSI, 4(1):1-6.

Bannett, W. L., \& Segerberg, A. (2012). The Logic of Connective Action. Information, Communication \& Society, 15(5): 739-768.

Barisione, M., Michailidou, A., \& Airoldi, M. (2017). Understanding a digital movement of opinion: the case of \#RefugeesWelcome. Information, Communication \& Society, 22(8):1145-1164.

Castells, M. (2012). Networks of outrage and hope - social movements in the Internet AGe. Chichester, UK: Wiley.

Drone Emprit. (2018, Desember 6). Perbandingan Lengkap Tagar Kampanye Digital. Retrieved from Drone Emprit: https://pers.droneemprit.id/de-perbandingan-lengkap-tagar-kampanye-digital/

Fitriah, E. (2014). Personal Values Dan Internal Political Efficacy Terhadap Partisipasi Politik Mahasiswa Pemilih Pemula. Jurnal UIN Sunan Gunung Djati Bandung, 1(2):244 - 254.

Gao, R. W. (2016). Hashtags and information virality in networked social movement: examining. Online Information Review, 40(7):1-26.

Hendrik, D. (2010). Variabel-variabel yang Mempengaruhi Rendahnnya Partisipasi Politik Masyarakat dalam Pilkada Walikota dan Wakil Walikota Padang Tahun 2008. Jurnal Demokrasi, 9(2):137-148.

Howard, P. N., Duffy, A., Freelon, D., Hassain, M., Mari, W., \& Mazaid, M. (2011). Opening Closed Regimes: What Was the Role of Social Media During the Arab Spring? SSRN Electronic Journal, 1-30. 
Jenkins, H. (2016). Chapter: 'Youth Voice, Media, and Political Engagement: Introducing the Core Concepts'. In H. Jenkins, S. Shresthova, L. Gamber-Thompson, N. Kligler-Vilenchik, \& A. M. Zimmerman, any media necessary: The new youth activism (pp. 1-62). New York: NY University Press.

Juditha, C., \& Darmawan, J. (2018). Penggunaan Media Digital dan Partisipasi Politik Generasi Mienial. Jurnal Penelitian Komunikasi dan Opini Publik, 22(2):94-109.

Knoll, J., Matthes, J., \& Heiss, R. (2018). The Social Medial Political Participation Model: A Goal Systems Theory Perspective. The International Journal of Research into New Media Technologies, 1-22.

Kuncoro, M. W. (2018). Media Sosial, Trust, dan Partisipasi Politik Pada Pemilih Pemula. Prosiding Seminar Nasional Psikologi Unissula: penguatan keluarga di zaman now (pp. 161-169). Semarang: Unissula.

Laksmitha, N., \& Susanto, E. (2019). Partisipasi Politik Generasi Milenial di Instagram dalam Pemilu 2019. Koneksi, 3(1):250-254.

Lotan, G., Graeff, E., Ananny, M., Gaffney, D., Pearce, I., \& boyd, D. (2011). The Revolutions Were Tweeted: Information Flows During the 2011 Tunisian and Egyptian Revolutions. International Journal of Communication: 5(5):1375-1405.

Martin, J. A. (2016). Digital Platforms and Differential Gains Campaign News, Online Expression, and Political Participation. Electronic News, 10(4):243-259.

Matulessy, A. (2013). Political Efficacy, Political Trust dan Collective Self Esteem dengan Partisipasi dalam Gerakan Mahasiswa. Jurnal Penelitian Psikologi, 4(1):84- 106.

Morissan. (2014). Media Sosial Dan Partisipasi Sosial Di Kalangan Generasi Muda. Jurnal Visi Komunikasi, 13(1): 50-68.

Mujani, S., Liddle, R., \& Ambardi, K. (2012). Kuasa rakyat : analisis tentang perilaku memilih dalam pemilihan legislatif dan presiden Indonesia pasca-Orde Baru. Jakarta: Mizan Media Utama.

Nahon, K., \& Hemsley, J. (2013). Going Viral. Cambridge, UK: Polity Press Cambridge.

Pemprov DKI Jakarta. (2018). Data Jumlah Penduduk Provinsi DKI Jakarta Berdasarkan Kelompok Usia dan Jenis Kelamin. Retrieved from Data Jakarta: http://data.jakarta.go.id/dataset/data-jumlah-pendudukprovinsi-dki-jakarta-berdasarkan-kelompok-usia-per-kelurahan

Plutzer, E. (2002). Becoming a habitual voter: Inertia, resources, and growth in young adulthood. American Political Science Review, 96(1):41-56.

Rachman, D. A. (2018, 1 Juli). Survei LSI: Kampanye \#2019GantiPresiden Semakin Populer dan Disukai. Retrieved from Kompas: https://nasional.kompas.com/read/2018/07/10/17040371/survei-lsi-kampanye2019gantipresiden-semakin-populer-dan-disukai

Ratnamulyani, I. A., \& Maksudi, B. (2018). Peran Media Sosial Dalam Peningkatan Partisipasi Pemilih Pemula Dikalangan Pelajar Di Kabupaten Bogor. Jurnal Ilmu-ilmu Sosial dan Humaniora, 20(2):154-161.

Sloam, J. (2018). \#Votebecause: Youth mobilisation for the referendum on British membership of the Uropean Union. New Media \& Society, 20(11) 4017-4034.

Small, T. A. (2011). What The hashtag. Information, Communication \& Society, 14(6):872-895.

The Economist Intelligence Unit. (2016). Democracy Index 2016: Revenge of the "deplorables". Retrieved from The Economist Intelligence Unit: https://www.transparency.org.nz/docs/2017/Democracy_Index_2016.pdf

The Economist Intelligence Unit. (2017). Democracy Index 2017: Free speech under attack. Retrieved from The Economist Intelligence

Unit: https://spcommreports.ohchr.org/TMResultsBase/DownLoadFile?gId=34079

The Economist Intelligence Unit. (2018). Democracy Index 2018: Me too? : Political participation, protest and democracy. Retrieved from The Economist Intelligence Unit: https://275rzy1ul4252pt1hv2dqyufwpengine.netdna-ssl.com/wp-content/uploads/2019/01/Democracy_Index_2018.pdf

The Economist Intelligence Unit. (2019). Democracy Index 2019:A year of democratic setbacks and popular protest. Retrieved from The Economist Intelligence Unit: https://www.eiu.com/topic/democracy-index

We Are Social. (2020). Indonesia Digital 2019: Media Sosial. Retrieved from We Are Social: https://websindo.com/indonesia-digital-2019-media-sosial/

Weeks, B. E., Lane, D., Kim, D., Lee, S., \& Kwak, N. (2017). "Incidental Exposure, Selective Exposure, and Political Information Sharing: Integrating Online Exposure Patterns and Expression on Social Media. Journal of Computer-Mediated Communication, 22(6): 363-379.

Yamamoto, M., Nah, S., \& Bae, S. (2019). Social media prosumption and online political participation: An examination of online communication processes. New Media \& Society, 22(10):1885-1902.

Yolanda, H. P., \& Halim, U. (2020). Partisipasi Politik Online Generasi Z pada Pemilihan Presiden 2019. Coverage, 10(2):30-39.

Zamir, M. H. (2015). Diffusion of protest information in twitter during shahbag movement of bangladesh. Proceedings of the American Society for Information Science and Technology (pp. 51(1):1-4). Computer Science. 